\title{
Meta-Analysis of the Impact of Job Embeddedness on Employee Attitudes and Employee Performance: A Study on Commercial Banks in Egypt
}

\author{
Wageeh Nafei ${ }^{1}$ \\ ${ }^{1}$ University of Sadat City, Egypt \\ Correspondence: Wageeh Nafei, University of Sadat City, Menoufia, Egypt. E-mail: dr.wageeh1965@yahoo.com
}

Received: August 4, 2014

Accepted: November 25, 2014

Online Published: January 20, 2015

doi:10.5539/ijbm.v10n2p196

URL: http://dx.doi.org/10.5539/ijbm.v10n2p196

\begin{abstract}
Background: Job Embeddedness (JE) is a core construct in the literature. However, there is considerably less evidence on its positive effects on Employee Attitudes (EA) and Employee Performance (EP).

Purpose: The objective of this study is to provide empirical evidence on the relationships between JE, EA and EP. This paper also seeks to present the theoretical development of JE, Job Satisfaction (JS), Organizational Commitment (OC), EP and their application to employees at Egyptian Commercial Banks (ECB) practices.
\end{abstract}

Research Design/Methodology: The method applied is to assess positive JE (JE Questionnaire, Mitchell et al., 2001), JS (JS Survey, Judge, \& Bono, 2001; Best \& Thurston, 2004), OC (OC Questionnaire, Porter et al., 1974; Trimble, 2006) and EP (EP Questionnaire, Black \& Porter, 1991; Caligiuri, 1997). Out of the 382 questionnaires that were distributed to employees at $\mathrm{ECB}, 315$ usable questionnaires were returned, a response rate of $82 \%$.

Findings: The results indicated the expected significant positive relationships between JE, JS, OC and EP. In other words, fit, links and sacrifice significantly correlated with EA and EP. The results also supported the hypothesized model. The study findings support the view that JE, JS, OC, EP are related constructs.

Practical Implications: The study suggests that ECB can improve EA and EP by influencing its JE, specifically, by developing fit, links and sacrifice. The study provided that it is necessary to pay more attention to the dimensions of JE as a key source for organizations to enhance the competitive advantage which is of prime significance for EA and EP.

Originality/Value: JE is valuable for evaluating employee retention at ECB. The study observes that there is a critical shortage of JE and that a greater understanding of the factors that influence the JE, JS, OC and EP, including fit, links and sacrifice, is of great importance. Therefore, this study examines the relationship between JE, JE, JS, OC and EP among employees at ECB.

Keywords: job embeddedness, employee attitudes, employee performance

\section{Introduction}

Job Embeddedness (JE) is composed of factors such as the overall fit employees have with the organization. It would yield positive outcomes. JE should lead to the development of human and social capital for two reasons. First, for highly embedded individuals, there is good fit of the employees' existing knowledge, skills and abilities with the requirements of the organization that provides opportunities for the natural extension and development of additional and complimentary skills. Second, the highly embedded employees have many links with more important individuals which provide opportunities to develop additional social capital. In fact, there is a positive relationship between JE and social capital but declines are found in social capital development over time ( $\mathrm{Ng} \mathrm{\&}$ Feldman, 2010).

JE theory represents one of these new perspectives (Holtom et al., 2008), focusing on factors that encourage an employee to remain with an organization. Several studies reveal that JE predicts incremental variation in turnover after controlling for traditional turnover predictors, such as job satisfaction and quit intentions (Crossley et al., 2007; Mallol et al., 2007).

JE is comprised of (1) the links one has to others, (2) the fit with the organization and community, and (3) how 
much one would have to sacrifice to change jobs (Lee et al., 2004; Holtom \& Inderrieden, 2006).

JE represents rich social ties, job fit, and personal investment in a job or organization and the community that in turn creates opportunities for the employee to extend and develop new skills and social ties with others (Holtom et al., 2006).

JE has numerous features; these are (a) work or organizational options by way of choosing your clients, (b) empowerment, or mentoring activities, and (c) non-worker social embeddedness (Van Emmerik \& Sanders, 2004) which includes direct links to family, non-work activities, off-the-job interests, and job and embeddedness in the organization (Mitchell et al., 2001).

\section{Conceptual Background}

\subsection{Job Embeddedness}

The idea behind JE is that it is a force attracting the individual towards surviving in the organization (Mitchell, et al., 2001). It focuses on a set of forces that attract the individual towards the survival in the organization, as JE depends on the prediction of the reasons of the individual belonging to the organization and his desire to leave it (Cho \& Son, 2012).

JE reflects employees' decisions to participate broadly and directly, and it moves scholarly attention beyond dissatisfaction-induced leaving. More aptly, JE is a retention (or "antiwithdrawal") construct (Dong-Hwan \& Jung-Min, 2012).

It is relatively a new concept and is under-researched in the hospitality management and marketing literature (Karatepe \& Ngeche, 2011).

It encompasses the total forces on an individual that cause the person to remain at his/her current job. JE has been empirically demonstrated to impact work-related behaviors such as turnover, performance, absenteeism and citizenship behaviors ( $\mathrm{Ng} \&$ Feldman, 2009).

JE has been conceptualized to consist of two dimensions: on-the-job (organizational) embeddedness and off-the-job (community) embeddedness. On-the-JE refers to the degree to which individuals are immersed in their organizations, while off-the-JE represents the degree to which individuals are immersed in their communities. On-the-JE better predicts employee job performance than does the off-the-JE. Furthermore, the On-the-JE better predicts employee retention than does the off-the-JE. Each embeddedness dimension is composed of three facets: fit, links, and sacrifice (Allen, 2006).

It is a new construct developed to capture a more comprehensive view of the employee-employer relationship than is typically reflected by attitudinal measures such as satisfaction or commitment. JE is a constellation of influences which enmesh or embed people within organizations. Consequently, the embedded employee either finds it more difficult to leave or does not want to leave the organization to which they have become a part. It is an assemblage of psychological, social, and financial influences that determine employee retention. JE is the combined material, financial, and psychological factors that keep a person from leaving his or her job. Theoretically, workplace friendships could increase JE by creating social links, perceptions of fit and greater sacrifice of having to leave work friends if a new job opportunity was present. JE is conceptualized as influencing the decision to remain through the level of links a person has to other people or activities, the extent that the person's job and community are congruent with the other aspects of their life, and the sacrifices a person would make in the process of leaving their employment (Mitchell et al., 2001).

If JE is indeed a broad-based retention (antiwithdrawal) construct and if it captures a sizable portion of the "decision to participate," both on- and off-the-JE should predict not only employee turnover, but also other withdrawal behaviors, such as decreasing organizational citizenship behavior, decreasing performance, and increasing absence. Further, the explained variance in these withdrawal behaviors should exceed that explained by job satisfaction and organizational commitment. However, the effect of on-the-JE on absences and turnover may be reduced to zero when researchers control for satisfaction and commitment. Further, off-the-JE predicts absences and turnover, and it may do so even when satisfaction and commitment are controlled for. That is, leaving a job may have significant effects on an individual's off-the-job life, especially if he or she has to relocate to find new employment. More specifically, people who are embedded in their communities should want to keep their jobs (Hulin, 1998).

High levels of JE indicate that a person feels a sense of compatibility between his or her personal career needs, goals and values and those of the job and organization; experiences positive formal and informal connections between himself or herself and the team or organization; and perceives the costs of leaving the job as being too 
high (Mitchell et al., 2001).

\subsection{The Dimensions of Job Embeddedness}

One previous study does suggest that JE consists of three dimensions. They are as follows (Mitchell et al., 2001).

\subsubsection{Ability to Comply with the Organization: Fit}

This dimension refers to the level of the individual satisfaction towards the organization to which he belongs. The individual's ability to comply with the organization is defined in light of the plans he puts as regards his job future and goals which he seeks to achieve, as well as the extent of compatibility of his personal values with the organizational ones (Khattak et al., 2012).

There is an important determinant of the employee's ability to comply with the work environment, including the extent of the availability of the basic requirements, which enable him to perform its functions successfully, whether those requirements pertain to the employee himself (package of skills, knowledge and experience) or they belong to the organization (to provide a suitable working environment for the establishment of individual tasks entrusted out) (Mitchell et al., 2001). The level of the individual agrees with the external environment representing an important dimension of embeddedness job, but the results of many previous studies indicate the weakness of its impact on the level of the individual's embeddedness within the organization (Lee et al., 2004).

So, the researcher is to study the impact of the internal environment at the level of on-the-JE as the individual's ability to comply with the organization and its goals affects his feelings toward it. The higher this ability, the lower the gap between the values and goals of the individual and the values and objectives of the organization, increasing the quality of the job, and the demand for voluntary work within the organization.

\subsubsection{Ability to Build a Good Network of Organizational Relationships: Links}

They are the second dimension of JE, and indicate the level of the relationship between the employee to others within the organization. It is characterized as formal or informal, and the results indicate several studies that the stronger these relations, the higher the level of JE (Harris et al., 2011; Holtom \& ONeil, 2004).

It must be noted that the demographic characteristics of the individual play an important role in his ability to build a network of good relations inside and outside of work. Individuals of older age have the ability to develop these relations thanks to their wisdom and the ability to achieve a balance between the different variables within and outside the work environment. Those individuals with long experience in the work invest those experiences in the development of their relationships with others, and then they are more job-embedded compared with new workers at the organization (Greene, 2012).

In light of the above, it can be said that the existence of good relations between individuals and each other on the one hand, and between them and the management of the organization on the other hand, contributes to the quality of job life, and also the size of the voluntary work within the organization.

\subsubsection{Sacrifice Borne by the Individual If He Left the Organization}

Sacrifice refers to the cost of alternative opportunity that will be borne by the individual because he left his job, whether the current financial cost, or the moral cost (Mitchell, et al., 2001). Some argue that it can rely on JE as a means to alleviate the unpleasant events in the work environment. We find that the staff who is available to have a high level of JE deal with the crisis as an opportunity that can be exploited to increase their productivity and the feeling of happiness in the work environment (Reitz \& Anderson,. 2011).

In light of the above, it can be said that the rise in the size of the sacrifices, both the physical and moral, which can be borne by the individual as a result of leaving the work of the organization, will have a large impact on the level of JE, and the quality of work life. Therefore, the size of the voluntary work performed by employees within the organization is affected too.

\subsection{Employee Attitudes}

There are two dimensions of EA. They are JS and OC. A number of previous researchers have reported mixed findings on the relationship between JS and OC. For instance, Busch et al. (1998) found a significant relationship between JS and OC. Other researchers (Chiu-Yueh, 2000) found that JS was a significant predictor of OC. Some other researchers found a positive correlation between JS and OC, which means that the high level of JS leads to higher OC (Freund, 2005).

Other researchers argued that JS reflects immediate affective reactions to the job while commitment to the organization develops more slowly after the individual forms more comprehensive valuations of the employing 
organization, its values, and expectations and one's own future in it. Therefore, JS is seen as one of the determinants of OC (Mannheim et al., 1997).

It is expected that highly satisfied workers will be more committed to the organization. Higher education is not immune to the problem of low JS; in fact, educational leaders have increased the number of research studies that try to identify factors that affect JS (Davis, 2001; Grace \& Khalsa, 2003; Scarpinato, 2001; Truman, 1999).

\subsubsection{Job Satisfaction}

Job satisfaction (JS) can be defined as employees' satisfaction level regarding their jobs and work conditions (Gohel, 2012).

JS level is relevant to employees' expectations about job itself. Therefore, if employees' satisfaction as to job expectations is provided, it is likely that it may increase employees' level of JS (Yang, 2010). It can be described as an affective case as a result of evaluation of individual's own work experience (Al Jenaibi, 2010) or an attitudinal phenomenon that individuals assess their JS as regarding past events and current impressions (Ko, 2012).

JS is a subjective affective response related to employees' impressions toward their jobs. Therefore, it isn't seen, but it can be observed through individual's behavior. JS can be stated as the extent to which outcomes meet expectations. JS occurs when employees try to get the rewards that they believe in or exceed their achievements (Islam et al., 2012)

JS includes many attitudinal objects connected with each other. These objects are relevant to job itself, wage, career facilities, management style, colleagues, and the like. Satisfaction of employees working in hotel businesses may produce positive results such as increase in productivity, creation of competitive advantage, reduction of optional labor turnover rate, resultant customer satisfaction and so forth. Individual and organizational variables are determining features in the formation of JS (Çetin \& Basım, 2011).

Organizational variables are listed as work conditions, wage, financial rewards, relationship with colleagues, form of government, job structure, career opportunities, work-life balance, role ambiguity; on the other hand, individual variables involve age, gender, education, seniority, personality traits, beliefs, values, and core competence (Rayton, 2006).

JS can be measured in terms of satisfaction with pay, promotion, coworkers, supervision and work or an overall rating of satisfaction. An overall measure is generally taken using the respondents' general perception of how satisfied they are with their job (Mulki et al., 2006).

There are two dimensions of job satisfaction. They are internal satisfaction and external satisfaction (Judge \& Bono, 2001; Best \& Thurston, 2004):

- Internal Satisfaction: It is the opportunities to demonstrate abilities, sense of achievement obtained from work, ethical values of the work, opportunities to provide services.

- External Satisfaction: It is job content, salary, unobstructed channels for promotion, work environment and equipment.

\subsubsection{Organizational Commitment}

Organization Commitment (OC) is the strong belief in and acceptance of the organizational goals and values, willingness to exert considerable effort on behalf of the organization, and a definite desire to maintain organizational membership (Porter et al., 1974). Individuals may become committed to an organization for many reasons: a person may stay with an organization because the organization's values, mission, and goals align with his/her own; another person may stay with the same organization because leaving may impact his/her prestige, benefits, or social networks; yet another may be committed to the organization due to a sense of obligation. Each of these three commitments (affective, continuance, and normative) are independent types of commitment experienced at different levels by all individuals of an organization (Meyer \& Allen, 1997).

OC considered is a three dimensional construct comprising affective, continuance and normative (Boehman, 2006; Canipe, 2006; Turner \& Chelladurai, 2005; Greenberg, 2005; Allen \& Meyer, 1996; Karrasch, 2003).

1) Affective commitment refers to an employee's connection through an emotional bond with, linkage to or engagement in the organization, while continuance commitment refers to the employee's perceptions of the benefits and advantages that may be lost when one leaves the relevant organization (Meyer \& Allen, 1991).

2) Normative commitment refers to an employee's sense of indebtedness towards the relevant organization. Thus, employees may feel obligated to stay at their organization because of social norms (Meyer \& Allen, 1991). 
3) Continuance commitment may develop as employees recognize that they have accumulated investments (Becker, 1960) that may be lost if they leave their current organization, or if alternative employment possibilities are limited.

Employees who are strongly committed to their organization are less likely to leave (Delobbe \& Vandenberghe, 2000; Lumley, 2009; Spector, 2008).

Employees who are committed to their organizations may easily accept and adhere to the organizational objectives and goals (Valentine et al., 2002).

\subsection{Employee Performance}

Performance is a reflection of the organization's ability to achieve its goals (Miller \& Broamiley, 1990). It is a combination of resources and capabilities of the organization that are being used efficiently and effectively in order to achieve its objectives (Collis \& Montgomrey, 1995).

Performance is the level of the outputs of the organization after conducting operations on its inputs. Performance is the output of the activities that occur within the organization (Wit \& Meyer, 1998).

Individual performance has become a topical issue in today's business environment, so much so that organizations go to great lengths to appraise and manage it (Armstrong \& Baron, 1998).

Individual job performance is a function of knowledge, skills, abilities, and motivation directed at role prescribed behavior, such as formal job responsibilities (Campbell, 1999).

Job performance is a multidimensional construct consisting of task dimension and contextual dimension (Borman $\&$ Motowidlo, 1993). A review of literature indicated individual differences such as gender (Caligiuri \& Tung, 1999; Sinangil \& Ones, 2003), Big Five Personality (e.g., Dalton \& Wilson, 2000; Caligiuri, 2000; Mol et al., 2005), self-monitoring personality (Caligiuri \& Day, 2000), goal orientation (Wang \& Takeuchi, 2007), task and people orientation, cultural flexibility (Shaffer et al., 2006), non-ethnocentrism (Hechanova et al., 2003), communicational ability, relational ability, stress tolerance (Holopainen \& Bjorkman, 2005), and previous international experience (Varma, Toh, \& Budhwar, 2006) related to expatriate job performance.

Hence, after a thorough review of the different concepts of performance, it can be argued that performance in its simplest form is the desired result which the organization seeks to achieve efficiently and effectively.

\section{Research Model}

The proposed comprehensive conceptual model is presented in Figure (1). The diagram below shows that there is one independent variable of JE.

There are two dependent variables of EA and EP. It shows the rational links among the variables. The research model is as shown in Figure (1) below.

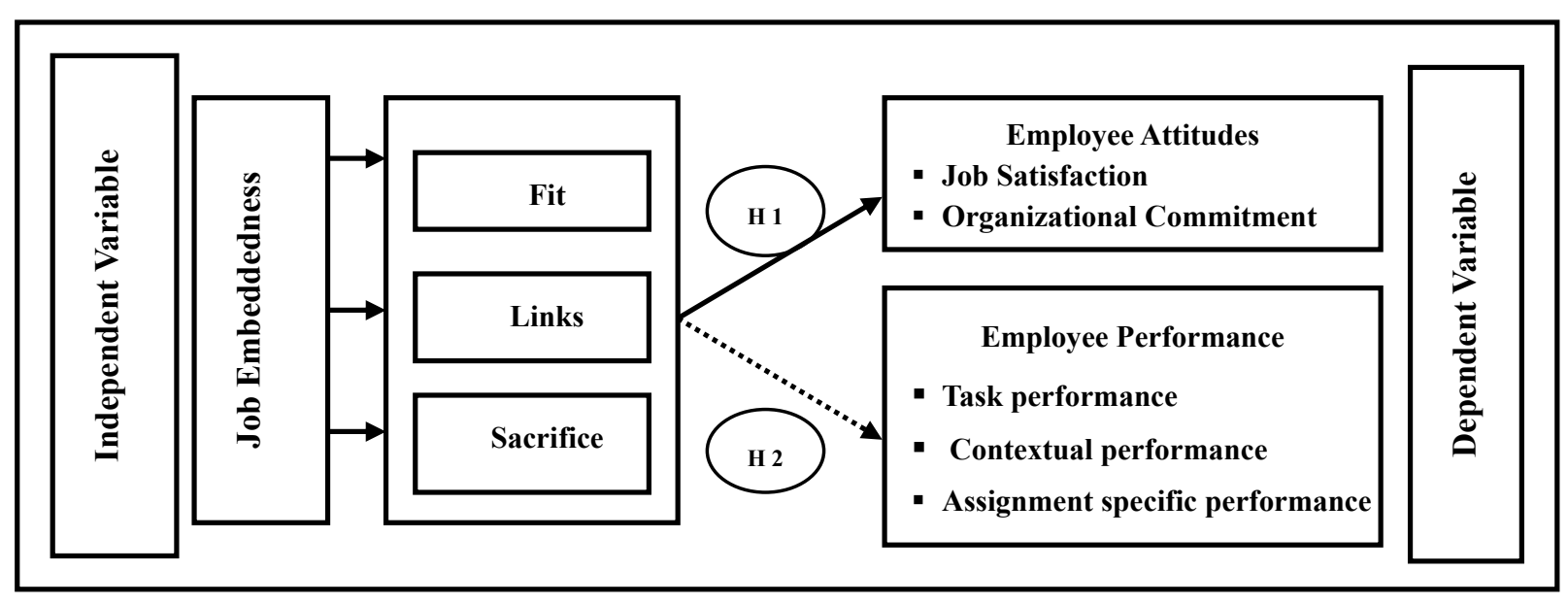

Figure 1. Proposed comprehensive conceptual model

The research framework suggests that JE has an impact on EA (JS, OC), and EP. JE as measured consists of three dimensions. They are fit, links, and sacrifice (Mitchell et al., 2001). 
JS is measured in terms of internal satisfaction and external satisfaction (Judge \& Bono, 2001; Best \& Thurston, 2004).

OC is measured in terms of affective, continuance, and normative commitment (Allan \& Meyer, 1990, Meyer et al., 1993). EP is measured in terms of task performance, contextual performance, and assignment specific performance (Black \& Porter, 1991; Caligiuri, 1997).

\section{Research Questions and Hypotheses}

The researcher found the research problem through two sources. The first source is to be found in previous studies, and it turns out that there is a lack in the number of literature reviews that dealt with the analysis of the relationship between JE, JS, OC and EP for employees at ECB. This called for the researcher to test this relationship in the Egyptian environment.

The second source is the pilot study, which was conducted in an interview with (30) employees at ECB in order to identify the relationship between JE, JS, OC and EP for employees at ECB. The researcher found several indicators; notably the important and vital role that could be played by JE in improving JS, OC and EP at Commercial Banks in Egypt.

The research process includes both questions and hypotheses. The research questions of this study are as follows:

Q1: What is the nature and the extent of the relationship between JE (Fit, Links, and Sacrifice) and JS at Commercial Banks in Egypt.

Q2: What is the statistically significant relationship between JE (Fit, Links, and Sacrifice) and OC at Commercial Banks in Egypt.

Q3: What is the nature of the relationship between JE (Fit, Links, and Sacrifice) and EP at Commercial Banks in Egypt.

The following hypotheses were developed to test if there is a significant correlation between JE, OC and JP.

H1: JE (Fit Links, and Sacrifice) has no significant effect on JS at Commercial Banks in Egypt.

H2: JE (Fit, Links, and Sacrifice) has no significant impact on OC at Commercial Banks in Egypt.

H3: JE (Fit, Links, and Sacrifice) has no significant influence on EP at Commercial Banks in Egypt.

\section{Research Methods}

\subsection{Population and Sample}

The study subjects are employees at the ECB. The total population is 66536 employees. Determination of respondent sample size was calculated using the formula (Daniel, 1999):

$$
n=\frac{N \times(Z)^{2} \times P(1-P)}{d^{2}(N-1)+(Z)^{2} \times P(1-P)}
$$

The number of samples obtained by 382 employees at the ECB is presented in Table 1 .

Table 1. Distribution of the sample size

\begin{tabular}{llll}
\hline Bank Type & $\begin{array}{l}\text { Number } \\
\text { Population }\end{array}$ & Percentage & Sample Size \\
\hline General Commercial Banks & 52564 & $79 \%$ & $382 \times 79 \%=302$ \\
Joint Commercial Banks & 11977 & $18 \%$ & $382 \times 18 \%=69$ \\
Foreign Branches of Banks & 1995 & $3 \%$ & $382 \times 3 \%=11$ \\
Total & $\mathbf{6 6 5 3 6}$ & $\mathbf{1 0 0 \%}$ & $\mathbf{3 8 2} \mathbf{1 0 0 \%}=\mathbf{3 8 2}$ \\
\hline
\end{tabular}

Source: Central Bank of Egypt, Economic Magazine, 2012.

\subsection{Method of Data Collection}

A survey-based descriptive research design is used. The study was carried out at ECB. The questionnaire included three pages.

A covering letter was attached to the questionnaire, explaining the instructions for completing the questionnaire. It included four questions, relating to recognizing JE, JS, OC, EP biographical information of employees at ECB. 
Data collection took approximately two months. About 382 survey questionnaires were distributed by employing diverse modes of communication such as in person and post. Multiple follow-ups yielded 315 statistically usable questionnaires. Survey responses were $82 \%$.

Table 2. Sample distribution

\begin{tabular}{|c|c|c|c|}
\hline Variables & Classification & Number & Percentage \\
\hline \multirow{9}{*}{ 1- Job Title } & General Manager & 22 & $7.0 \%$ \\
\hline & Deputy General Manager & 22 & $7.0 \%$ \\
\hline & Agent General Manager & 22 & $7.0 \%$ \\
\hline & Deputy Manager & 37 & $11.7 \%$ \\
\hline & Controller & 37 & $11.7 \%$ \\
\hline & Excellent Banker & 47 & $14.9 \%$ \\
\hline & Banker A & 45 & $14.3 \%$ \\
\hline & Banker B & 83 & $26.3 \%$ \\
\hline & Total & 315 & $100 \%$ \\
\hline \multirow{3}{*}{ 2- Marital Status } & Married & 217 & $69.9 \%$ \\
\hline & Single & 98 & $31.1 \%$ \\
\hline & Total & 315 & $100 \%$ \\
\hline \multirow{4}{*}{ 3- Age } & Less than 30 years & 126 & $40.0 \%$ \\
\hline & From 30 to 45 & 141 & $44.8 \%$ \\
\hline & More than 45 & 48 & $15.2 \%$ \\
\hline & Total & 315 & $100 \%$ \\
\hline \multirow{3}{*}{ 4- Educational Level } & University Education & 143 & $45.4 \%$ \\
\hline & Post Graduate Studies & 172 & $54.0 \%$ \\
\hline & Total & 315 & $100 \%$ \\
\hline \multirow{4}{*}{ 5- Period of Experience } & Less than 5 years & 66 & $21.0 \%$ \\
\hline & From 5 to 10 & 215 & $68.3 \%$ \\
\hline & More than 10 & 34 & $10.8 \%$ \\
\hline & Total & 315 & $100 \%$ \\
\hline
\end{tabular}

\subsection{Research Variables and Methods of Measuring}

The 18-item scale JE section is based on Mitchell et al. (2001). There were six items measuring fit, six items measuring links, and six items measuring sacrifice.

The 10-item scale JS section is based on Judge and Bono (2001); Best and Thurston (2004). There were six items measuring internal satisfaction and six items measuring external satisfaction.

The 18-item scale OC section is based on Allan and Meyer (1990), Meyer et al. (1993). There were six items measuring affective, six items measuring continuance, and six items measuring normative.

The 17-item scale EP section is based on Black and Porter (1991); Caligiuri (1997). There were five items for task performance, five for contextual performance, and seven for assignment specific performance. Responses to all items scales were anchored on a five (5) point Likert scale for each statement which ranges from (5) "full agreement," (4) for "agree," (3) for "neutral," (2) for "disagree," and (1) for "full disagreement."

\subsection{Methods of Data Analysis and Testing Hypotheses}

The researcher has employed the following methods: (1) The Alpha Correlation Coefficient (ACC), (2) Multiple Regression Analysis (MRA), and (3) F-test and T-test.

\section{Hypotheses Testing}

Before testing the hypotheses and research questions, descriptive statistics were performed to find out means and standard deviations of JE, JS, OC and EP. Table 3 lists the mean and standard deviation among variables. The mean of each variable is more than 3 , and this result indicates that the study subjects in general have a higher level of JE, JS, OC and EP.

The different facets of JE (fit, links, and sacrifice) are examined. Most respondents identified the presence of sacrifice $(\mathrm{M}=3.37, \mathrm{SD}=0.94)$. This was followed by fit $(\mathrm{M}=3.22, \mathrm{SD}=1.13)$, and links $(\mathrm{M}=3.15, \mathrm{SD}=0.95)$.

The different facets of JS (internal satisfaction and external satisfaction) are examined. Most respondents identified the presence of internal satisfaction $(\mathrm{M}=3.68, \mathrm{SD}=1.33)$. This was followed by external satisfaction 
$(\mathrm{M}=3.67, \mathrm{SD}=1.26)$.

The different facets of OC (affective, continuance and normative) are examined. Most respondents identified the presence of affective dimension $(\mathrm{M}=3.76, \mathrm{SD}=1.23)$. This was followed by continuance dimension $(\mathrm{M}=3.68$, $\mathrm{SD}=1.31)$, and normative dimension $(\mathrm{M}=3.67, \mathrm{SD}=1.27)$.

Table 3. Mean and standard deviations of JE, OC and JP

\begin{tabular}{llll}
\hline Variables & The Dimension & Mean & Standard Deviation \\
\hline \multirow{4}{*}{ JE } & Fit & 3.22 & 1.13 \\
& Links & 3.15 & 0.95 \\
& Sacrifice & 3.37 & 0.94 \\
\cline { 2 - 4 } & Total Measurement & $\mathbf{3 . 2 5}$ & $\mathbf{0 . 9 7}$ \\
\hline \multirow{3}{*}{ JS } & Internal Satisfaction & 3.68 & 1.32 \\
& External Satisfaction & 3.67 & 1.25 \\
\cline { 2 - 4 } OC & Total Measurement & $\mathbf{3 . 6 9}$ & $\mathbf{1 . 2 8}$ \\
& The Affective Dimension & 3.76 & 1.23 \\
& The Continuance Dimension & 3.68 & 1.31 \\
& The Normative Dimension & 3.67 & 1.27 \\
\cline { 2 - 4 } & Total Measurement & $\mathbf{3 . 5 0}$ & $\mathbf{1 . 1 8}$ \\
\multirow{3}{*}{ EP } & Task Performance & 3.70 & 1.21 \\
& Contextual Performance & 3.63 & 1.31 \\
& Assignment Specific Performance & 3.62 & 1.26 \\
\cline { 2 - 4 } & Total Measurement & $\mathbf{3 . 6 5}$ & $\mathbf{1 . 2 3}$ \\
\hline
\end{tabular}

The different facets of JP (task performance, contextual performance, and assignment-specific performance) are examined. Most respondents identified the presence of task performance $(M=3.70, S D=1.21)$. This was followed by contextual performance $(\mathrm{M}=3.63, \mathrm{SD}=1.31)$, and assignment specific performance $(\mathrm{M}=3.62, \mathrm{SD}=1.27)$.

\subsection{Evaluating Reliability}

Table 4. Reliability of JE, OC and JP

\begin{tabular}{llll}
\hline Variables & The Dimension & Number of Statement & ACC \\
\hline \multirow{3}{*}{ JE } & Fit & 6 & 0.87 \\
& Links & 6 & 0.76 \\
& Sacrifice & 6 & 0.77 \\
& Total Measurement & $\mathbf{1 8}$ & $\mathbf{0 . 9 3}$ \\
\multirow{3}{*}{ JS } & Internal Satisfaction & 6 & 0.96 \\
& External Satisfaction & 6 & 0.95 \\
& Total Measurement & $\mathbf{1 8}$ & $\mathbf{0 . 9 7}$ \\
\multirow{3}{*}{ OC } & The Affective Dimension & 6 & 0.97 \\
& The Continuance Dimension & 6 & 0.96 \\
& The Normative Dimension & 6 & 0.96 \\
& Total Measurement & $\mathbf{1 8}$ & $\mathbf{0 . 9 8}$ \\
\multirow{2}{*}{ EP } & Task Performance & 5 & 0.96 \\
& Contextual Performance & 5 & 0.96 \\
& Assignment Specific Performance & 7 & 0.96 \\
& Total Measurement & $\mathbf{1 7}$ & $\mathbf{0 . 9 8}$ \\
\hline
\end{tabular}

ACC was decided to exclude variables that had a correlation coefficient of less than 0.30 when the acceptable limits of ACC range from 0.60 to 0.80 , in accordance with levels of reliability analysis in social sciences (Nunnally $\&$ Bernstein, 1994). To assess the reliability of the data, Cronbach's alpha test was conducted. Table (4) shows the reliability results for JE, OC and JP. All items had alphas above 0.60 and were therefore excellent, according to Langdridge's (2004) criteria. 
The 18 items of JE are reliable due to the fact that the ACC is 0.94 . The fit, which consists of six items, is reliable since the ACC is 0.87 while the six items related to links is reliable as the ACC is 0.76 . Furthermore, the sacrifice, which consists of six items, is reliable due to the fact that the ACC is 0.77 .

The 10 items of JS are reliable due to the fact that the ACC is 0.98 . The internal satisfaction, which consists of five items, is reliable since the ACC is 0.96 while the six items related to external satisfaction is reliable as the ACC is 0.95 .

The 18 items of OC are reliable because the ACC is 0.98 . The six items of affective scales are reliable due to the fact that the ACC is 0.97 . The continuance, which consists of six items, is reliable since the ACC is 0.96 . The six items related to normative are reliable as ACC is 0.96 .

The 17 items of JP are reliable because the ACC is 0.98 . The five items of task performance scales are reliable due to the fact that the ACC is 0.96 . The contextual performance, which consists of five items, is reliable since the ACC is 0.96 . The seven items related to assignment-specific performance are reliable as ACC is 0.96 .

\subsection{The Correlation among the Research Variables}

Table 5 shows correlation coefficients among the research variables, and results indicate the presence of significant correlation between variables (JE, JS, OC, and EP). The level of JE of employees is average (Mean=3.39; $\mathrm{SD}=0.988$ ), while JS is higher (Mean=3.67; SD 1.28) which led to high level of OC (Mean=3.50; SD. 1.28) and EP (Mean $=3,65$; SD. 1,24).

Table 5. Means, standard deviations and intercorrelations among variables

\begin{tabular}{lllllll}
\hline Variables & Mean & Std. Deviation & JE & JS & OC & EP \\
\hline Job Embeddedness & 3.25 & 0.97 & 1.000 & & & \\
Job Satisfaction & 3.67 & 1.28 & $0.38^{* *}$ & 1.00 & & \\
Organizational Commitment & 3.50 & 1.17 & $0.37^{* *}$ & $0.99^{* *}$ & 1.00 & \\
Employee Performance & 3.64 & 1.23 & $0.38^{* *}$ & $0.97^{* *}$ & $0.97^{* * *}$ & 1.00 \\
\hline
\end{tabular}

Table 5 reveals the existence of a positive correlation between JE and JS $(\mathrm{R}=0.375 ; \mathrm{P}<0.01)$, which means that the high level of JE leads to higher JS. The table shows the existence of a positive correlation between JE and OC $(\mathrm{R}=$ 0.369; $\mathrm{P}<0.01$ ), which means that the high level of JE leads to higher OC. Table (5) refers to the existence of a positive correlation between JE and $\mathrm{EP}(\mathrm{R}=0.378 ; \mathrm{P}<0.01)$ implying that the high level of JE led to high level of EP.

According to Table (5), there is a positive correlation between JS and $\mathrm{OC}(\mathrm{R}=0.99 ; \mathrm{P}<0.01)$, which means that the high level of JS leads to higher OC. The table shows that there is a positive correlation between JS and EP $(\mathrm{R}=0.97$; $\mathrm{P}<0.01$ ), which means that the high level of JS leads to higher EP. Table (5) refers that there is a positive correlation between $\mathrm{OC}$ and $\mathrm{EP}(\mathrm{R}=0.97 ; \mathrm{P}<0.01)$ implying that the high level of $\mathrm{OC}$ led to high level of EP.

\subsection{The Relationship between JE (Fit) and JS}

Table 6. MRA Results for JE (Fit) and JS

\begin{tabular}{|c|c|c|c|}
\hline The Variables of JE (Fit) & Beta & $\mathrm{R}$ & R2 \\
\hline $\begin{array}{l}\text { 1. I have a relationship of friendship and love with all the members of the } \\
\text { working group. }\end{array}$ & 0.105 & 0.288 & 0.082 \\
\hline My job enables me to exploit my skills and talents well. & 0.099 & 0.256 & 0.065 \\
\hline My values and goals are consistent with the values of the organization. & $0.310^{* *}$ & 0.156 & 0.024 \\
\hline I can achieve my professional goals through work in this organization. & $0.305^{* *}$ & 0.269 & 0.072 \\
\hline $\begin{array}{l}\text { I feel satisfied about my progress, during my professional career in this } \\
\text { organization. }\end{array}$ & 0.151 & 0.344 & 0.118 \\
\hline 6. If I stay in this organization, I will achieve more of my goals. & 0.102 & 0.350 & 0.112 \\
\hline - $\quad$ Multiple Correlation Coefficients (MCC) & 0.421 & & \\
\hline - Determination of Coefficient (DF) & 0.177 & & \\
\hline - The Value of Calculated $\mathrm{F}$ & 11.071 & & \\
\hline - $\quad$ Degree of Freedom & 6,308 & & \\
\hline - $\quad$ The Value of Indexed F & 2.80 & & \\
\hline - $\quad$ Level of Significance & 0.01 & & \\
\hline
\end{tabular}


According to Table (6), the regression-coefficient between JE (Fit) and JS is $\mathrm{R}=0.42$ and $\mathrm{R}^{2}=0.18$. This means that the JS can be explained by the dimensions of JE, for example, "My values and goals are consistent with the values of the organization" $\left(\beta=0.310, \mathrm{R}=0.156\right.$, and $\left.\mathrm{R}^{2}=0.024\right)$, "I can achieve my professional goals through work in this organization" $\left(\beta=0.305, R=0.269\right.$, and $\left.R^{2}=0.072\right)$, and "I feel satisfied about my progress, during my professional career in this organization" $\left(\beta=0.151, \mathrm{R}=0.344\right.$, and $\left.\mathrm{R}^{2}=0.118\right)$. Because of the calculated $\mathrm{F}(82.828)$ more than indexed F (2.80) at the statistical significance level of 0.01 , the null hypothesis is rejected.

\subsection{The Relationship between JE (Links) and JS}

Table 7. The relationship between JE (Links) and JS

\begin{tabular}{|c|c|c|c|}
\hline The Variables of JE (Links) & Beta & $\mathrm{R}$ & $\mathrm{R}^{2}$ \\
\hline 1. I interact constantly with my colleagues at work. & 0.035 & 0.119 & 0.014 \\
\hline A lot of co-workers depend on me to help achieve their work. & 0.123 & 0.296 & 0.087 \\
\hline The current system allows the possibility of forming interacting work teams & 0.073 & 0.156 & 0.024 \\
\hline $\begin{array}{l}\text { Regular informal meetings are held to strengthen relationships among } \\
\text { workers. }\end{array}$ & 0.057 & 0.269 & 0.072 \\
\hline I feel that my current job satisfies my need for appreciation. & 0.018 & 0.344 & 0.118 \\
\hline The organization allows all members to participate in work committees. & $0.233^{*}$ & 0.350 & 0.122 \\
\hline - $\quad$ Multiple Correlation Coefficients (MCC) & 0.394 & & \\
\hline - $\quad$ Determination of Coefficient (DF) & 0.155 & & \\
\hline The Value of Calculated F & 9.428 & & \\
\hline - $\quad$ Degree of Freedom & 6,308 & & \\
\hline - $\quad$ The Value of Indexed F & 2.80 & & \\
\hline - $\quad$ Level of Significance & 0.01 & & \\
\hline
\end{tabular}

Note. $* \mathrm{P}<.05 ; * * \mathrm{P}<.01$.

According to Table 7, the regression-coefficient between JE (Links) and JS is $\mathrm{R}=0.757$ and $\mathrm{R}^{2}=0.572$. This means that the JS can be explained by the dimensions of JE, for example, "The organization allows all members to participate in work committees" $\left(\beta=0.233, \mathrm{R}=0.350\right.$, and $\left.\mathrm{R}^{2}=0.122\right)$, "A lot of co-workers depend on me to help achieving their work" $\left(\beta=0.123, R=0.296\right.$, and $\left.R^{2}=0.087\right)$, and "I feel that my current job satisfies my need for appreciation" ( $\beta=0.018, \mathrm{R}=0.344$, and $\left.\mathrm{R}^{2}=0.118\right)$.

Thus, the null hypothesis is rejected because JE (Links) and JS have a statistical relationship at the significance level of 0.01 .

\subsection{The Relationship between JE (Sacrifice) and JS}

Table 8. The relationship between JE (Sacrifice) and JS

\begin{tabular}{lllll}
\hline The & Variables of JE (Sacrifice) & Beta & $\mathrm{R}$ & $\mathrm{R} 2$ \\
\hline 1. & I have a lot of freedom to choose how to set out my goals. & $0.170^{* *}$ & 0.102 & 0.010 \\
2. $\quad$ I feel that colleagues at work show me a lot of respect and appreciation. & 0.115 & 0.286 & 0.081 \\
3. $\quad$ Promotion opportunities in this job are excellent. & 0.079 & 0.165 & 0.027 \\
4. $\quad$ I get a good profit meeting level of the my performance sufficiently. & 0.098 & 0.263 & 0.069 \\
5. $\quad$ The organization provides a distinct package of health care for workers. & $0.441^{* *}$ & 0.330 & 0.108 \\
6. $\quad$ The organization provides a distinct package of rewards at retirement. & 0.148 & 0.278 & 0.077 \\
\hline - $\quad$ Multiple Correlation Coefficients (MCC) & 0.377 & & \\
- $\quad$ Determination of Coefficient (DF) & 0.142 & & \\
- $\quad$ The Value of Calculated F & 8.486 & & \\
- $\quad$ Degree of Freedom & 6,308 & & \\
- $\quad$ The Value of Indexed F & 2.80 & & \\
- $\quad$ Level of Significance & 0.01 & & \\
\hline
\end{tabular}

Note. $* \mathrm{P}<.05 ; * * \mathrm{P}<.01$.

According to Table (8), the regression-coefficient between JE (Sacrifice) and JS is $\mathrm{R}=0.775$ and $\mathrm{R}^{2}=0.483$. This means that the JS can be explained by the dimensions of JE, for example, "I have a lot of freedom to choose how to set out my goals" ( $\beta=0.170, R=0.102$, and $\left.R^{2}=0.010\right)$, "The organization provides a distinct package of health 
care for workers" $\left(\beta=0.441, \mathrm{R}=0.330\right.$, and $\left.\mathrm{R}^{2}=0.108\right)$, and "The organization provides a distinct package of rewards at retirement" $\left(\beta=0.148, \mathrm{R}=0.278\right.$, and $\left.\mathrm{R}^{2}=0.077\right)$.

Therefore, there is enough empirical evidence to reject the null hypothesis because JE (Sacrifice) and JS have a statistical relationship at the significance level of 0.01 .

\subsection{The Relationship between JE (Fit) and OC}

Table 9. MRA results for JE (Fit) and OC

\begin{tabular}{|c|c|c|c|}
\hline The Variables of JE (Fit) & Beta & $\mathrm{R}$ & $\mathrm{R} 2$ \\
\hline $\begin{array}{l}\text { 1. I have a relationship of friendship and love with all the members of the working } \\
\text { group. }\end{array}$ & 0.138 & 0.289 & 0.083 \\
\hline 2. My job enables me to exploit my skills and talents well. & 0.073 & 0.255 & 0.065 \\
\hline 3. My values and goals are consistent with the values of the organization. & $0.306^{* *}$ & 0.151 & 0.022 \\
\hline 4. I can achieve my professional goals through work in this organization. & $0.286^{* *}$ & 0.262 & 0.068 \\
\hline $\begin{array}{l}\text { 5. I feel satisfied about my progress, during my professional career in this } \\
\text { organization. }\end{array}$ & 0.158 & 0.340 & 0.115 \\
\hline 6. If I stay in this organization, I will achieve more of my goals. & 0.095 & 0.340 & 0.115 \\
\hline - $\quad$ Multiple Correlation Coefficients (MCC) & 0.417 & & \\
\hline - $\quad$ Determination of Coefficient (DF) & 0.174 & & \\
\hline - $\quad$ The Value of Calculated F & 10.779 & & \\
\hline Degree of Freedom & 6,308 & & \\
\hline - $\quad$ The Value of Indexed F & 2.80 & & \\
\hline Level of Significance & 0.01 & & \\
\hline
\end{tabular}

Note. $* \mathrm{P}<.05$;** $\mathrm{P}<.01$.

According to Table (9), the regression-coefficient between JE (Fit) and $\mathrm{OC}$ is $\mathrm{R}=0.514$ and $\mathrm{R}^{2}=0.264$. This means that the OC can be explained by the dimensions of JE, for example, "My values and goals are consistent with the values of the organization" $\left(\beta=0.306, R=0.151\right.$, and $\left.\mathrm{R}^{2}=0.022\right)$, "I can achieve my professional goals through work in this organization" $\left(\beta=0.286, \mathrm{R}=0.262\right.$, and $\left.\mathrm{R}^{2}=0.068\right)$, and "I feel satisfied about my progress, during my professional career in this organization" $\left(\beta=0.158, \mathrm{R}=0.340\right.$, and $\left.\mathrm{R}^{2}=0.115\right)$. Because of the calculated $\mathrm{F}(23.521)$ more than indexed F (2.80) at the statistical significance level of 0.01 , the null hypothesis is rejected.

6.7 The Relationship between JE (Links) and OC

Table 10. The relationship between JE (Links) and OC

\begin{tabular}{|c|c|c|c|}
\hline The Variables of JE (Links) & Beta & $\mathrm{R}$ & $\mathrm{R}^{2}$ \\
\hline 1. I interact constantly with my colleagues at work. & 0.021 & 0.108 & 0.011 \\
\hline 2. A lot of co-workers depend on me to help achieve their work. & 0.117 & 0.291 & 0.084 \\
\hline 3. The current system allows the possibility of forming interacting work teams & 0.069 & 0.151 & 0.022 \\
\hline 4. Regular informal meetings are held to strengthen relationships among workers. & 0.053 & 0.262 & 0.068 \\
\hline 5. I feel that my current job satisfies my need for appreciation. & 0.024 & 0.340 & 0.115 \\
\hline 6. The organization allows all members to participate in work committees. & $0.234^{*}$ & 0.346 & 0.119 \\
\hline - $\quad$ Multiple Correlation Coefficients (MCC) & 0.397 & & \\
\hline - $\quad$ Determination of Coefficient (DF) & 0.150 & & \\
\hline - $\quad$ The Value of Calculated $\mathrm{F}$ & 9.025 & & \\
\hline - $\quad$ Degree of Freedom & 6,308 & & \\
\hline - $\quad$ The Value of Indexed F & 2.80 & & \\
\hline - Level of Significance & 0.01 & & \\
\hline
\end{tabular}

Note. $* \mathrm{P}<.05 ; * * \mathrm{P}<.01$.

According to Table 10, the regression-coefficient between JE (Links) and $\mathrm{OC}$ is $\mathrm{R}=0.507$ and $\mathrm{R}^{2}=0.257$. This 
means that the OC can be explained by the dimensions of JE, for example, "The organization allows all members to participate in work committees" $\left(\beta=0.234, \mathrm{R}=0.346\right.$, and $\left.\mathrm{R}^{2}=0.119\right)$, " $\mathrm{A}$ lot of co-workers depend on me to help achieving their work" $\left(\beta=0.117, \mathrm{R}=0.291\right.$, and $\left.\mathrm{R}^{2}=0.084\right)$, and "I feel that my current job satisfies my need for appreciation" ( $\beta=0.024, \mathrm{R}=0.340$, and $\left.\mathrm{R}^{2}=0.115\right)$. Thus, the null hypothesis is rejected because JE (Links) and OC have a statistical relationship at the significance level of 0.01 .

6.8 The Relationship between JE (Sacrifice) and OC

Table 11. The relationship between JE (Sacrifice) and OC

\begin{tabular}{llll}
\hline The Variables of JE (Sacrifice) & Beta & R & R2 \\
\hline 1. I have a lot of freedom to choose how to set out my goals. & $0.163^{* *}$ & 0.094 & 0.008 \\
2. I feel that colleagues at work show me a lot of respect and appreciation. & 0.116 & 0.285 & 0.081 \\
3. Promotion opportunities in this job are excellent. & 0.077 & 0.162 & 0.026 \\
4. I get a good profit meeting level of my performance sufficiently. & 0.104 & 0.259 & 0.067 \\
5. The organization provides a distinct package of health care for workers. & $0.451^{* * *}$ & 0.330 & 0.108 \\
6. The organization provides a distinct package of rewards at retirement. & 0.156 & 0.275 & 0.075 \\
\hline - $\quad$ Multiple Correlation Coefficients (MCC) & 0.374 & & \\
- Determination of Coefficient (DF) & 0.140 & & \\
- The Value of Calculated F & 8.340 & & \\
- Degree of Freedom & 6,308 & & \\
- The Value of Indexed F & 2.80 & & \\
\hline
\end{tabular}

Note. $* \mathrm{P}<.05 ; * * \mathrm{P}<.01$.

According to Table (11), the regression-coefficient between JE (Sacrifice) and OC is $R=0.516$ and $\mathrm{R}^{2}=0.266$. This means that the OC can be explained by the dimensions of JE, for example, "I have a lot of freedom to choose how to set out my goals" $\left(\beta=0.163, \mathrm{R}=0.094\right.$, and $\left.\mathrm{R}^{2}=0.008\right)$, "The organization provides a distinct package of health care for workers" $\left(\beta=0.451, R=0.330\right.$, and $\left.R^{2}=0.108\right)$, and "The organization provides a distinct package of rewards at retirement" $\left(\beta=0.156, \mathrm{R}=0.275\right.$, and $\left.\mathrm{R}^{2}=0.075\right)$. Therefore, there is enough empirical evidence to reject the null hypothesis because JE (Sacrifice) and OC have a statistical relationship at the significance level of 0.01 .

\subsection{The Relationship between JE (Fit) and EP}

Table 12. MRA results for JE (Fit) and EP

\begin{tabular}{|c|c|c|c|}
\hline The Variables of JE (Fit) & Beta & $\mathrm{R}$ & $\mathrm{R} 2$ \\
\hline $\begin{array}{l}\text { 1. I have a relationship of friendship and love with all the members of the } \\
\text { working group. }\end{array}$ & 0.199 & 0.310 & 0.096 \\
\hline 2. My job enables me to exploit my skills and talents well. & 0.039 & 0.271 & 0.073 \\
\hline 3. My values and goals are consistent with the values of the organization. & $0.291^{* * *}$ & 0.159 & 0.025 \\
\hline 4. I can achieve my professional goals through work in this organization. & $0.254^{* *}$ & 0.261 & 0.068 \\
\hline $\begin{array}{l}\text { 5. I feel satisfied about my progress, during my professional career in this } \\
\text { organization. }\end{array}$ & 0.170 & 0.343 & 0.117 \\
\hline 6. If I stay in this organization, I will achieve more of my goals. & 0.081 & 0.348 & 0.121 \\
\hline - $\quad$ Multiple Correlation Coefficients (MCC) & 0.423 & & \\
\hline - $\quad$ Determination of Coefficient (DF) & 0.179 & & \\
\hline - $\quad$ The Value of Calculated F & 11.158 & & \\
\hline - $\quad$ Degree of Freedom & 6,308 & & \\
\hline The Value of Indexed F & 2.80 & & \\
\hline - $\quad$ Level of Significance & 0.01 & & \\
\hline
\end{tabular}

Note. $* \mathrm{P}<.05 ; * * \mathrm{P}<.01$. 
According to Table (12), the regression-coefficient between JE (Fit) and EP is $\mathrm{R}=0.747$ and $\mathrm{R}^{2}=0.558$. This means that the EP can be explained by the dimensions of JE, for example, "My values and goals are consistent with the values of the organization" $\left(\beta=0.291, R=0.159\right.$, and $\left.R^{2}=0.025\right)$, "I can achieve my professional goals through work in this organization" $\left(\beta=0.254, \mathrm{R}=0.261\right.$, and $\left.\mathrm{R}^{2}=0.068\right)$, and "I have a relationship of friendship and love with all the members of the working group" $\left(\beta=0.199, R=0.310\right.$, and $\left.R^{2}=0.096\right)$. Because of the calculated $F$ (11.158) more than indexed F (2.80) at the statistical significance level of 0.01 , the null hypothesis is rejected.

\subsection{The Relationship between JE (Links) and EP}

Table 13. The relationship between JE (Links) and EP

\begin{tabular}{lllll}
\hline The Variables of JE (Links) & Beta & $\mathrm{R}$ & $\mathrm{R} 2$ \\
\hline 1. & I interact constantly with my colleagues at work. & 0.010 & 0.097 & 0.009 \\
2. & A lot of co-workers depend on me to help achieve their work. & 0.113 & 0.295 & 0.087 \\
3. & The current system allows the possibility of forming interacting work teams & 0.082 & 0.163 & 0.026 \\
4. $\quad$ Regular informal meetings are held to strengthen relationships among & 0.047 & 0.261 & 0.068 \\
& workers. & 0.031 & 0.343 & 0.117 \\
5. $\quad$ I feel that my current job satisfies my need for appreciation. & $0.230^{*}$ & 0.348 & 0.121 \\
6. $\quad$ The organization allows all members to participate in work committees. & 0.392 & & \\
\hline - $\quad$ Multiple Correlation Coefficients (MCC) & 0.153 & & \\
- $\quad$ Determination of Coefficient (DF) & 9.303 & & \\
- $\quad$ The Value of Calculated F & 6,308 & & \\
- $\quad$ Tegree of Freedom & 2.80 & & \\
- & Level of Significance & 0.01 & & \\
\hline
\end{tabular}

Note. $* \mathrm{P}<.05 ; * * \mathrm{P}<.01$.

According to Table (13), the regression-coefficient between JE (Links) and EP is $\mathrm{R}=0.757$ and $\mathrm{R}^{2}=0.572$. This means that the EP can be explained by the dimensions of JE, for example, "The organization allows all members to participate in work committees" $\left(\beta=0.230, \mathrm{R}=0.348\right.$, and $\left.\mathrm{R}^{2}=0.121\right)$, "A lot of co-workers depend on me to help achieving their work" $\left(\beta=0.113, R=0.295\right.$, and $\left.R^{2}=0.087\right)$, and "I feel that my current job satisfies my need for appreciation" ( $\beta=0.031, \mathrm{R}=0.343$, and $\left.\mathrm{R}^{2}=0.117\right)$. Thus, the null hypothesis is rejected because JE (Links) and EP have a statistical relationship at the significance level of 0.01 .

\subsection{The Relationship between JE (Sacrifice) and EP}

Table 14. The relationship between JE (Sacrifice) and EP

\begin{tabular}{llll}
\hline The Variables of JE (Sacrifice) & Beta & $\mathrm{R}$ & $\mathrm{R} 2$ \\
\hline 1. I have a lot of freedom to choose how to set out my goals. & $0.161^{* *}$ & 0.084 & 0.007 \\
2. I feel that colleagues at work show me a lot of respect and appreciation. & 0.088 & 0.288 & 0.082 \\
3. Promotion opportunities in this job are excellent. & 0.086 & 0.175 & 0.030 \\
4. I get a good profit meeting the level of my performance sufficiently. & 0.119 & 0.268 & 0.071 \\
5. The organization provides a distinct package of health care for workers. & $0.492^{* *}$ & 0.348 & 0.121 \\
6. The organization provides a distinct package of rewards at retirement. & 0.149 & 0.288 & 0.082 \\
- Multiple Correlation Coefficients (MCC) & 0.387 & & \\
- Determination of Coefficient (DF) & 0.150 & & \\
- The Value of Calculated F & 9.060 & & \\
- Degree of Freedom & 6,308 & & \\
- The Value of Indexed F & 2.80 & & \\
- Level of Significance & 0.01 &
\end{tabular}

According to Table (14), the regression-coefficient between JE (Sacrifice) and EP is $R=0.775$ and $\mathrm{R}^{2}=0.483$. This means that the EP can be explained by the dimensions of JE, for example, "I have a lot of freedom to choose how to set out my goals" ( $\beta=0.492, R=0.348$, and $\left.R^{2}=0.121\right)$, "I have a lot of freedom to choose how to set out my 
goals" ( $\beta=0.161, \mathrm{R}=0.084$, and $\left.\mathrm{R}^{2}=0.007\right)$, and "I get a good profit meeting level of my performance sufficiently" $\left(\beta=0.119, R=0.268\right.$, and $\left.R^{2}=0.071\right)$. Therefore, there is enough empirical evidence to reject the null hypothesis.

\section{Research Finding}

The findings support the view that the dimensions of JE (fit, links, and sacrifice) were negatively related with JS (internal satisfaction and external satisfaction).

Our findings support the view that the dimensions of JE (fit, links, and sacrifice) were negatively related with OC (affective, continuance and normative).

The results of this research indicate a direct effect relationship between JE and OC. The results are consistent with research (Caldwell, 2012; Dinger, 2010; Karatepe \& Ngeche, 2012; Reitz et al., 2010; Abad 2010; Watsou, 2011; Chen \& Lim, 2012; Clinton et al., 2012).

The findings support the view that the dimensions of JE (fit, links, and sacrifice) were negatively related with EP (task performance, contextual performance, and assignment specific performance).

On the other hand, the results support the view that the dimensions of EP were positively related with EP. The results support the view that JE significantly influences EP. The findings reveal that the JE was positively related with EP. Overall findings suggest that JE does affect EP.

\section{Recommendations}

- There is a need to pay attention to JE as an effective strategy to improve relations between employees on the one hand, and their superiors, on the other hand, in order to improve the level of EP within the organization.

- There is a need to focus on the three dimensions of JE and use them to increase the feelings of JS and OC of employees in the organization.

- It is found out that an individual's ability to comply with the organization (Fit), and its goals affect JS and OC. This ability decreased the gap between the values and goals of the individual and the values and goals of the organization and this increases feelings of JS and OC among individuals.

- As for the ability to build a network of good organizational relationships (links), the existence of good relations between individuals and the management of the organization contributes to increase feelings of JS and OC among employees.

- The high volume of moral and material sacrifices that can be borne by the individual as a result of his employment in the organization will affect the level of EP, and this increases the feelings of JS and OC in the organization.

- Promoting and supporting organizational culture encourages JE of employees. This can be achieved through the support and consolidation of mutual trust between the management of the organization, its leadership and its staff, as the high level of JE softens the negative effects of the work environment. This is achieved by increasing the capacity of the individual for compatibility with the organization and the development of relationships with others at all levels of the organization.

\section{Limitations and Future Research}

The current study was subject to certain constraints. The major constraint in this study was that it was conducted in a single sector. The study would have been more authoritative had more than one sector been used for the investigation.

Further, the study would have been more beneficial if the data analysis had differentiated among employees, as it would have given a better indication of which group of specialized staff would be more inclined to leave the organization.

A random sampling method, as opposed to the purposive sampling method applied here, might have rendered results that were more generalizable as a whole. Owing to the limited scope of the study, it is recommended that further studies be undertaken in order to address these limitations.

In addition, it is recommended that the environmental dimension of JE be included to add depth to the study and to provide a more holistic view of JE with regard to OC.

The results show potential for the analysis of the relationship between OC and JE, as well as differences among the biographical groups' experiences of these constructs in the Egyptian services industry.

The study is an original research that adds new insights to the psychological factors that influence the retention of critical and scarce skills. The results of this study may be used as a basis for informing effective human resource 
retention strategies.

\section{Conclusions and Implications}

The results indicate that JE significantly influenced JS, OC and EP. The current study has confirmed that the higher the relationship between employees and the organization, the more likely it is that employees will be committed to the organization. This results in tenured staff and the retention of critical skills (Mohlala et al., 2012).

The results suggest that human resource retention practices should be implemented to increase the perceived sacrifice (in terms of compensation and benefits) and the perceived fit (compatibility between the individual's career and job satisfaction needs and the organization's cultural values and practices) for employees with critical and scarce skills. Strengthening these employees' sense of JE by increasing the forces that keep them strongly connected to their jobs and the organization may lead to greater commitment levels and an incentive to stay with the respective organization.

Based on the results, it is suggested that human resource retention practices for staff members with scarce and critical skills should emphasize competitive remuneration, monetary and nonmonetary benefits and rewards, performance management initiatives that enhance person-job fit and person-organization fit, morale, motivation and interpersonal relationship building initiatives. The intention is therefore to create positive emotional bonds between people, supervisor and peer support, mentoring and coaching and career advancement planning.

According to Muteswa \& Ortlepp (2011), employees with critical skills leave organizations because of poor relationships between the employee and his/her immediate manager; a lack of career advancement plans; a poor match between the employee and the job or organization; uncompetitive compensation; rewards that are not linked to performance; the need to have stimulating and meaningful work; a lack of appreciation, recognition and rewards; insufficient coaching and feedback; aspects related to the dynamics of the work team; and insufficient alignment between the employee's work and the achievement of organizational objectives.

Lesabe and Nkosi (2007) suggest that compensation, benefit packages, morale and motivation, career development, leadership, nature of the job itself, training and development, performance management and work environment all have a bearing on an organization's ability to retain employees.

\section{References}

Allen, D. G. (2006). Do organizational socialization tactics influence newcomer embeddedness and turnover? Journal of Management, 32, 237-256. http://dx.doi.org/10.1177/0149206305280103

Allen, N. J., \& Meyer, J. P. (1996). Affective, Continuance, and Normative Commitment to the Organization: An Examination of Construct Validity. Journal of Vocational Behavior, 49, 252-276. http://dx.doi.org/10.1006/jvbe.1996.0043

Armstrong, M., \& Baron, A. (1998) Performance management: the new realities. London: Institute of Personnel and Development.

Becker, H. S. (1960). Notes on the concept of commitment. American Journal of Sociology, 66(1), 32-42. http://dx.doi.org/10.1086/222820

Best, M., \& Thurston, N. (2004). Measuring Nurse Job Satisfaction. Journal of Nursing Administration, 34 , 283-290. http://dx.doi.org/10.1097/00005110-200406000-00007

Boehman, J. (2006). Affective, continuance, and normative commitment among student affairs professionals. Unpublished doctoral dissertation, North Carolina State University, Raleigh, NC (ProQuest Digital Dissertations).

Borman, W. C., \& Motowidlo, S. J. (1993). Expanding the criterion domain to include elements of contextual performance. In N. Schmitt \& W. C. Borman (Eds.), Personnel selection in organizations (pp. 71-98). San Francisco: Jossey Bass.

Busch, T., Fallan, L., \& Pettersen, A. (1998). Disciplinary differences in job satisfaction self-efficacy, goal commitment and organizational commitment among faculty employees in Norwegian Colleges: An empirical assessment of indicators of performance. Quality in Higher Education, 4(2), 137-157. http://dx.doi.org/10.1080/1353832980040204

Caligiuri, P. M. (2000). The Big Five personality characteristics as predictors of expatriate's desire to terminate the assignment and supervisor-rated performance. Personnel Psychology, 53, 67-88. http://dx.doi.org/10.1111/j.1744-6570.2000.tb00194.x

Caligiuri, P. M., \& Tung, R. L. (1999). Comparing the success of male and female expatriates from a US-based 
multinational company. International Journal of Human Resource Management, 10, 763-782. http://dx.doi.org/10.1080/095851999340143

Campbell, J. P. (1999). The definition and measurement of performance in the new age. In D. R. Ilgen \& E. D. Pulakos (Eds.), The changing nature of performance: Implications for staffing, motivation, and development (pp. 399-429). San Francisco, Calif: Jossey-Bass.

Canipe, J. S. (2006). Relationships among trust, organizational commitment, perceived organizational support, and turnover intentions. Unpublished doctoral dissertation.

Cetin, F. (2011). The Effect of the Organizational Psychological Capital on the Attitudes of Commitment and Satisfaction: a Public Sample in Turkey. European Journal of Social Science, 21(3), 373-380.

Chiu-Yueh, T. (2000). A Study on the Relationship among Organizational Commitment, Job Satisfaction and Organizational Citizenship Behaviour of Nursing Personnel. Master's Thesis, Department of Human Resource Management. Retrieved on 23rd January, 2010 from http://etd.lib.nsusu.edu.tw/ETD_db/ETDsearch/view_etd?URN=etd-0725101-002148

Cho, D., \& Son, J. (2012). Job Embeddedness and Turnover Intentions: An Empirical Investigation of Construction IT Industries. International Journal of Advanced Science and Technology, 40, 101-110.

Collis, D., \& Montgomrey, C., (1995). Competing on Resources: Strategy in the 1995s.

Crossley, C. D., Bennett, R. J., Jex, S. M., \& Burnfield, J. L. (2007). Development of a global measure of job embeddedness and integration into a traditional model of voluntary turnover. Journal of Applied Psychology, 92(2), 1031-1042. http://dx.doi.org/10.1037/0021-9010.92.4.1031

Dalton, M., \& Wilson, M. (2000). The relationship of the five-factor model of personality to job performance for a group of Middle Eastern expatriate managers. Journal of Cross-Cultural Psychology, 31, 250-258. http://dx.doi.org/10.1177/0022022100031002007

Daniel, W. (1999). Biostatistics: A Foundation For Analysis in the Health Sciences (7th ed.). New York, John Wiley \& Sons.

Davis, R. H. (2001). Faculty recruitment and retention task force report. Boulder: University of Colorado.

Dong-Hwan, C., \& Jung-Min, S. (2011). Job Embeddedness and Turnover Intentions: An Empirical Investigation of Construction IT Industries. International Journal of Advanced Science and Technology, 40, 101-110.

Freund, A. (2005). Commitment and job satisfaction as predictors turnover intentions among welfare workers. Administration in Social Work, 29(2), 5-21. http://dx.doi.org/10.1300/J147v29n02_02

Gohel, K. (2012). Psychological Capital as a Determinant of Employee Satisfaction. International Referred Research Journal, 3(36), 34-37.

Grace, D. H., \& Khalsa, S. A. (2003). Re-recruiting faculty and staff: The antidote to today's high attrition. Independent School, 62(3), 20-27.

Greenberg, J. (2005). Managing Behavior in Organizations (4th ed.). Prentice-Hall, Englewood.

Greene, J. (2012). Job Embeddedness: Do the Interaction Effects of Attitude, Personality, and Exchange Relationships Detract from Performance? Dissertations, Theses and Capstone Projects. 504.

Harris, K. J, Wheeler, A. R., \& Kacmar, K. M. (2011). The Mediating Role of Organizational Job Embeddedness in the LMX-outcomes Relationships. Leadersh. Q., 22(2), 271-281. http://dx.doi.org/10.1016/j.leaqua.2011.02.003

Hechanova, R., Beehr, T. A., \& Christiansen, N. D. (2003). Antecedents and consequences of employees' adjustment to overseas assignments: A meta-analytic review. Applied Psychology, 52, 213-236. http://dx.doi.org/10.1111/1464-0597.00132

Holopainen, J., \& Bjrkman, I. (2005). The personal characteristics of the successful expatriate: A critical review of the literature and an empirical investigation. Personnel Review, 34(1), 37-50. http://dx.doi.org/10.1108/00483480510578476

Holtom, B. C., \& Inderrieden, E. J. (2006). Integrating the unfolding model and job embeddedness model to better understand voluntary turnover. Journal of Managerial Issues, 18, 435-452. http://dx.doi.org/10.1097/00005110-200405000-00005 
Holtom, B. C., \& O’Neill, B. S. (2004). Job embeddedness: A theoretical foundation for developing a comprehend sive nurse retention plan. Journal of Nursing Administration, 34, 216-227. http://dx.doi.org/10.1016/j.orgdyn.2006.08.007

Holtom, B. C., Mitchell, T. R., \& Lee, T. W. (2006). Increasing human and social capital by applying job embeddedness theory. Organizational $\quad$ Dynamics, 316-331. http://dx.doi.org/10.1080/19416520802211552

Holtom, B. C., Mitchell, T. R., Lee, T. W., \& Eberly, M. (2008). Turnover and retention research: A glance at the past, a closer review of the present, and a venture into the future. Academy of Management Annals, 2, 231-274.

Hulin, C. (1998). Behaviors, constructs and time: Potholes on the road well traveled. Invited address, annual meeting of the Society for Industrial and Organizational Psychology, Dallas.

Islam, R. Rasul, T., \& Wali, U. (2012). Analysis of the Factors that Affect Job Satisfaction: A Case Study on Private Companies Employees of Bangladesh. European Journal of Business and Management, 4(4), 35-46.

Judge, T. A., \& Bono, J. E. (2001). Relationship of core self-evaluation traits-self-esteem, generalized self-efficacy, locus of control, and emotional stability-with job-satisfaction and performance: A meta-analysis. Journal of Applied Psychology, 86, 80-92. http://dx.doi.org/10.1037/0021-9010.86.1.80

Karatepe, O. M., \& Ngeche, R. N. (2011). Does Job Embeddedness Mediate the Effect of Work Engagement on Job Outcomes? A Study of Hotel Employees in Cameroon. Journal of Hospitality Marketing and Management.

Karrasch, A. I. (2003). Antecedents and consequences of organizational commitment. Military Psychology, 15(3), 225-236. http://dx.doi.org/10.1207/S15327876MP1503_05

Khattak, F., Hussain, A., Mehmood, Q., Mumtaz, A., Rehman, U., Kasif, U., \& Rehman, K. (2012). Shrinking Employees Turnover Intention by applying Tools of Job Embeddedness (Used as a Mediator). Information Management and Business Review, 4(7), 370-378.

Ko, Wen-Hwa. (2012). The Relationships Among Professional Competence, Job Satisfaction and Career Development Confidence for Chefs in Taiwan. International Journal of Hospitality Management, 31, 1004-1011. http://dx.doi.org/10.1016/j.ijhm.2011.12.004

Lee, T. W., Mitchell, T. R., Sablynski, C. J., Burton, J. P., \& Holtom, B. C. (2004). The effects of organizational embeddedness on organizational citizenship, job performance, volitional absences, and voluntary turnover. Academy of Management Journal, 47, 711-722. http://dx.doi.org/10.2307/20159613

Mallol, C. M., Holtom, B. C., \& Lee, T. W. (2007). Job embeddedness in a culturally diverse environment. Journal of Business and Psychology, 22, 35-44. http://dx.doi.org/10.1007/s10869-007-9045-x

Mannheim, B., Baruch, Y., \& Tal, J. (1997). Alternative models for antecedents and outcomes of work centrality and job satisfaction of high-tech personnel. Human Relations, 50(2), 1537-1562. http://dx.doi.org/10.1177/001872679705001204

Meyer, J. P., \& Allen, J. N. (1997). Commitment in the Workplace-Theory, Research and Application. Sage Publications, Thousand Oaks, CA.

Meyer, J. P., \& Allen, N. J. (1991). A three-component conceptualization of organizational commitment. Human Resource Management Review, 1(1), 61-89. http://dx.doi.org/10.1016/1053-4822(91)90011-Z

Miller, K., \& Bromiley, P. (1990). Strategic Risk and Corporate Performance: An Analysis of Alternative Risk Measure. Academy of Management Journal, 33(4), 756-779. http://dx.doi.org/10.2307/256289

Mitchell T. R., Holtom, B. C., Lee, T. W., Sablynski, C. J., \& Erez, M. (2001). Why People Stay: Using Job Embeddedness to Predict Voluntary Turnover. Academy of Management Journal, 44(6), 1102-1121. http://dx.doi.org/10.2307/3069391

Mol, S. T., Born, M. P., Willemsen, M. E., \& Van Der Molen, H. T. (2005). Predicting expatriate job performance for selection purposes: A quantitative review. Journal of Cross-Cultural Psychology, 36(5), 590-620. http://dx.doi.org/10.1177/0022022105278544

Ng, T. W. H., \& Feldman, D. C. (2010). The impact of job embeddedness on innovation-related behaviors. Human Resource Management, 49(6), 1067-1087. http://dx.doi.org/10.1002/hrm.20390

Ng, T. W., \& Feldman, D. C. (2009). Occupational embeddedness and job performance. Journal of Organizational 
Behavior, 30, 863-891. http://dx.doi.org/10.1002/job.580

Porter, L. W., Steers, R. M., Mowday, R. T., \& Boulian, P. V. (1974). Organizational Commitment, Job Satisfaction, and Turnover among Psychiatric Technicians. Journal of Applied Psychology, 59, 603-609. http://dx.doi.org/10.1037/h0037335

Rayton, B. A. (2006). Examining the Interconnection of Job Satisfaction and Organizational Commitment: An Application of the Bivariate Probit Model. The International Journal of Human Resource Management, 17(1), 139-154. http://dx.doi.org/10.1080/09585190500366649

Reitz, O., \& Anderson, M., (2011). An Overview of Job Embeddedness. Journal of Professional Nursing, 27(5), 320-327. http://dx.doi.org/10.1016/j.profnurs.2011.04.004

Scarpinato, D. (2001). Faculty retention continues to suffer amid university budget cuts. Arizona Daily. Retrieved December 3, 2003, from http://wildcat.arizona.edu/papers/95/67/01_2.html

Shaffer, M. A., Harrison, D. A., Gregersen, H., Black, J. S., \& Ferzandi, L. A. (2006). You can take it with you: Individual differences and expatriate effectiveness. Journal of Applied Psychology, 91, 109-125. http://dx.doi.org/10.1037/0021-9010.91.1.109

Sinangil, H. K., \& Ones, D. S. (2003). Gender differences in expatriate job performance. Applied Psychology: An International Review, 52(3), 461-475. http://dx.doi.org/10.1111/1464-0597.00144

Truman State University. (1999). Retention of quality professors: Key to a successful liberal arts education? Kirksville, MO: American Association of University Professors.

Turner, B. A., \& Chelladurai, P. (2005). Organizational and occupational commitment, intention to leave, and perceived performance of intercollegiate coaches. Journal of Sport Management, 19, 193-211.

Valentine, S., Godkin, L., \& Lucero, M. (2002). Ethical context, organizational commitment, and person-organization fit. Journal of Business Ethics, 41(4), 349-360. http://dx.doi.org/10.1023/A:1021203017316

Varma, A., Toh, S. M., \& Budhwar, P. S. (2006). A new perspective on the female expatriate experience: The role of host country national categorization. Journal of World Business, 41, 112-120. http://dx.doi.org/10.1016/j.jwb.2006.01.010

Wang, M., \& Takeuchi, R. (2007). The role of goal orientation during expatriation: A cross-sectional and longitudinal investigation. Journal of Applied Psychology, 93(5), 1437-1445. http://dx.doi.org/10.1037/0021-9010.92.5.1437

Wit, B., \& Meyer, R. (1998). Strategy: Process, Content, Context: An International Perspective. Thompson Business Press.

Yang, Jen-Te. (2010). Antecedents and Consequences of Job Satisfaction in the Hotel Industry. International Journal of Hospitality Management, 29, 609-619. http://dx.doi.org/10.1016/j.ijhm.2009.11.002

\section{Copyrights}

Copyright for this article is retained by the author(s), with first publication rights granted to the journal.

This is an open-access article distributed under the terms and conditions of the Creative Commons Attribution license (http://creativecommons.org/licenses/by/3.0/). 